\title{
The Mediating Impact of SMEDAN Initiative on the Relationship Between CSFs and SMEs' Success: A Conceptual Paper
}

\author{
Babandi Ibrahim Gumel ${ }^{1, ~ *, ~ B a r j o y a l ~ B i n ~ B a r d a i ~}$ \\ ${ }^{1}$ Department of Finance, Faculty of Business Administration, LIGS University, Honolulu, Hawaii, USA \\ ${ }^{2}$ Faculty of Finance and Administrative Sciences, Al-Madinah International University, Kuala Lumpur, Malaysia \\ Email address: \\ bbdgumel@gmail.com (B. I. Gumel),barjoyai@Ims.mediu.edu.my (B. B. Bardai) \\ ${ }^{*}$ Corresponding author
}

\section{To cite this article:}

Babandi Ibrahim Gumel, Barjoyal Bin Bardai. The Mediating Impact of SMEDAN Initiative on the Relationship Between CSFs and SMEs' Success: A Conceptual Paper. International Journal of Business and Economics Research. Vol. 10, No. 2, 2021, pp. 66-75. doi: $10.11648 /$ j.ijber.20211002.12

Received: February 26, 2021; Accepted: March 11, 2021; Published: March 17, 2021

\begin{abstract}
Nigeria's federal government, after the oil boom of the 1970s, created policies, including the SMEDAN initiative, to trigger socio-economic development through entrepreneurship and small business development. Notwithstanding the importance of SMEs' socio-economic development and the Nigerian government's effort to support entrepreneurship and SMEs development, SMEs fail within the first five years. There is not enough information that can be used by SME owners/managers to develop best business practice policies to mitigate SMEs' failure and trigger socio-economic development. Critical success factor (CSFs) provides information that can be used to develop the best business practice to mitigate SMEs failure. Researchers stated that for owners/managers of SMEs to use CSFs models, they must replicate studies in new geographical areas or new industries. There is no CSFs model for the Nigerian location. The purpose is to position a CSFs model that can be used as information by owners/managers of SMEs to develop the best business policies to mitigate SME failures in Nigeria. This paper presents a thesis concepts where the researcher used a mixed research approach to position a CSFs model that can provide the information that can be used by owners/managers to mitigate SMEs failure and trigger socio-economic development. Mitigating SMEs' failure in Nigeria will reduce unemployment and poverty, which might trigger socio-economic development as envisaged by the federal government. This conceptual paper revealed the findings of the pilot study for the thesis were it was revealed that five variables impact SMEs' success in Jigawa State, Nigeria.
\end{abstract}

Keywords: Small and Medium Enterprises, SMEDAN, Critical Success Factor (CSF), Socio-economic Development (SED), Entrepreneurial Factors, Enterprise Factors, Environmental Factor

\section{Introduction}

Small businesses, otherwise referred to as small and medium enterprises (SMEs) are considered as one of the most critical sectors that grow nations through socio-economic developments $[2,25]$. SMEs are essential to the world economy and play a role in economic development [54], provides products and services [34], create value in an economy [66], drive industrialization [63], develop skills of managers [36], create wealth for nations [46], and above all employ citizens of nations [65]. SMEs also improve nations' research and development ability compared to larger firms [67].
Nations considered the generation of SMEs' employment ability as key to growing economies [21] and create wealth for citizens [48]. SMEs' ability to generate employment energizes policymakers to make policies for their success and sustainability [38]. There are pieces of evidence across nations that SMEs employ their citizens [35], in the United States [47], Europe [61], Poland, Germany, and Ukraine [10], Asia [72], Vietnam [71], Ecuador [70], Africa [1], and Nigeria [32]. Therefore, SMEs' most crucial roles in economies are their ability to generate employment and spur socio-economic development [1]. Countries establish institutions/agencies aimed at supporting the growth and development of SMEs. In 
the United States, there is the Small Business Administration (SBA), an agency to support the development of SMEs [60], while in Nigeria, there is the small and medium enterprises development agency (SMEDAN) with the same purpose of developing the sector [65].

There is a lack of information for small businesses to develop strategies to mitigate SMEs' failure [51]. Part of the knowledge and information is for SME owners and managers to develop policies that will result in best business practices that can influence SMEs' success [20]. Researchers have developed CSFs models that determine the factors influencing SMEs' success $[2,37]$. SMEs' success factors are critical because they serve as guides to mitigating challenges and failure and propel them to success [37]. According to Dugguh (2015), the information about SMEs' critical success factors enables owners/managers to formulate strategies for best business practices to mitigate challenges and failure. Lampadarios [37] and Alfaadhel [2] categorized critical success factors (CSFs) of SMEs into three: entrepreneurial factors, enterprise factors, and environmental factors. The entrepreneurial factors concern the owners/managers' activities in SMEs' operations [37]. The factors that concern the organization/firm/company itself are the enterprise factors, while the factors affecting the external environment are called environmental factors [2, 37].

A review of related literature revealed over $21 \mathrm{CSF}$ that influence SMEs' success without regard to location, industry, or operational area. Researchers stated the need to replicate research to determine SMEs' CSFs that apply to a new location or industry. Also, most of the existing CSFs for SME theories do not consider Government initiatives like SMEDAN to determine the CSFs that influence SMEs' success. The study investigates the seven CSFs selected for research to determine the influence on SMEs' success and further determine the SMEDAN initiative's impact on the relationship between the CSFs and SMEs' success in Nigeria. The study positioned a model that revealed CSFs that influences SMEs' success in Jigawa State, Nigeria.

\section{The Problem Statements}

Nigeria's discovery of oil in the early 1960s brought about the collapse of SMEs' development, which trigger difficult socio-economic development [52]. The end of the country's oil boom triggered the Nigerian government's efforts to develop entrepreneurship and small businesses for socio-economic development [22]. There are several programs/policies of Nigeria's federal government to develop entrepreneurship and SMEs, including in 2003 when SMEDAN was established to support SMEs development [64]. Despite the SMEDAN initiative and other Nigerian government efforts to develop the country's SMEs, researchers found that more than $80 \%$ of small businesses fail, resulting in massive unemployment among citizens [51]. Therefore, the effort to trigger socio-economic development through SMEs' development becomes retarded due to massive failure. There is the need to mitigate SMEs' failure to spur socio-economic development in Nigeria.

Obaje (2020) found that there is not enough information for
SME decision-makers to mitigate SMEs' failure in Nigeria. CFSs models served as information for SMEs to develop policies to mitigate failure [37]. There is no conclusive study that revealed CSFs that can mitigate Nigeria's SMEs' failure $[13,51]$. The existing CSFs model shows they are developed for specific geographical locations [14] or industries [37, 58] can only be applied to new locations or industries when replicated. The literature review also revealed that existing models do not consider government intervention in developing SMEs, such as the SMEDAN initiative [37, 43]. The study is replicated to develop the CSFs model for SMEs operating in Jigawa State, Nigeria. The SMEDAN initiative was introduced to find its impact on the relationship between CSFs and SMEs' success. The study is limited to Jigawa State Nigeria (one of the 36 States in the country) because of limited time and funding. Positioning a CSFs model for Jigawa State SMEs will enable owners/managers and policymakers to develop policies that will spur best business practices to mitigate failure. Mitigating SMEs' failure will reduce the unemployment rate and poverty and improve citizens' welfare, which might trigger socio-economic development.

The study was to position CSFs models for SMEs operating in Jigawa State, Nigeria, which will serve as sources of information to develop policies for best business practices that will mitigate SMEs' failure. Mitigating the failure will curt the unemployment and poverty rate and trigger socio-economic development: a feat that the Nigerian government wants to achieve through entrepreneurship and SME development.

\section{Research Objectives and Question}

The conceptual paper presented the theoretical/conceptual model and the result of a pilot study of a Ph.D. thesis that established the model's feasibility and viability. The study was to investigate the CSFs that influence SMEs' success in Jigawa State, Nigeria. Studies indicated several CSFs influencing the success of SMEs where their impacts vary from one location to another. The CSFs impact industries differently. Therefore, the study confirmed which of the many CSFs identified in the literature review impacts the SMEs operating in Jigawa State, Nigeria. Secondly, to determine the SMEDAN initiative's impact on SMEs' success, it is introduced as a mediating variable to investigate its impact of CSFs on SMEs success.

Therefore, the study determines the influence of seven identified CSFs (two entrepreneurial, three enterprise, and two environment factors) on SMEs' success that were operating in Jigawa State, Nigeria. The study was also to determine the mediating impact of the SMEDAN initiative on the relationship between seven identified CSFs and SME's success and further determine the general impact of the SMEDAN initiative on the success of SMEs. The aim was to position a model used by owners/managers of SMEs to develop best business practice policies to mitigate SMEs' failure by reducing unemployment and poverty levels that might trigger Nigeria's socio-economic development.

The study aims to achieve that by answering the central question: What are the critical success factors of small 
businesses operating in Jigawa State, Nigeria? This can be obtained by determining the answer to the questions: how do the seven CSFs (two entrepreneurial, three enterprise, and two environment factors) influence the success of SMEs?; how do the SMEDAN initiative influence the relationship between CSFs and the success of SMEs?; and how do the SMEDAN initiative impact on the relationship between CSFs and the general success of SMEs? The two entrepreneurial factors are prior work experience and management skills: education level. The three enterprise factors are financial resources, marketing, and strategic planning. The environment factors are legal and regulation, and technology influence.

\section{Theoretical Framework}

During the literature review, which was part of the secondary data collection, the researcher identified seven CSFs of SMEs without considering geographical location or industry of operation of the models but instead considered the significance of the CSFs in the findings of several CSFs models. The seven identified CSFs that are the study's independent variables were based on how they influence SMEs' success in other models. The CSFs identified were also identified as SMEDAN initiative areas of intervention to support SMEs' growth and development in Nigeria [50]. Therefore, the SMEDAN initiative is introduced as a mediating variable for the study. The purpose is to determine whether the SMEDAN initiative impacts the relationship between the identified CSFs and SMEs' success.

A further investigation into the various CSFs models revealed two that recognized the industrial organization model that considers the external environment factors as CSFs [2, 37]. Hitt et al. recognized both internal and external CSFs as influencing businesses' growth and sustainability. Unlike the internal factors that are purely controllable by management, according to the industrial organization model, the external environment factors can only be monitored and assessed to adjust the internal factors to improve performances and sustain growth [28]. Because the Lampadarios [37] model recognizes the environment CSFs, it is adopted as the study's framework. The theory categorizes the CSFs into three; entrepreneurial, enterprise, and environment factors. Based on the Lampadarios [37] framework, the seven identified CSFs were categorized into two entrepreneurial (prior work experience and management skills; and educational level), three enterprise (finance resources, marketing, and strategic planning), and two environment (legal and regulations; and technological influence) factors. The Lampadarios [37] framework was adopted and categorized the CSFs to position a CSFs model for SMEs operating in Jigawa State, Nigeria.

\section{Review of the Development of Research in the Area to the Knowledge Frontier}

The free-market economy booms of the 1980s triggered SMEs' recognition as the catalyst of innovation and job generation [44]. Even though SMEs are important to nations' socio-economic development, a continuous failure that negatively impacted the free-market economy's sustenance and SMEs that survived make little profit [69]. Policymakers embarked on studies to identify the factors influencing' e success or failure to trigger the free-market economy's improvement [55]. Models were developed between 1983 and 1984 to identify factors determining the success vs. failure of businesses $[5,6,33]$. The models do not predict businesses' success or failure correctly [56]. Similarly, the success vs. failure prediction model for Europe failed to make accurate predictions [39].

Earlier success vs. failure prediction models targeted larger firms [62], which used financial ratios or the Altman $\mathrm{Z}$ ratio for making predictions [23]. Similarly, Lussier and Corman (1996) found that financial ratios in predicting success vs. failure do not provide accurate results. Nevertheless, Lussier [43] stated that the models that utilize managerial variables are mostly accurate. Therefore, studies show that financial ratios for success vs. failure predictions for SMEs are not effective as in larger firms [7]. A study of 132 firms by El-Zayaty [24], which uses financial ratios for success vs. failure predictions, indicated that only five businesses failed within five years. Therefore, the use of qualitative variables to determine the success vs. failure of SMEs is effective and accurate [69]. Earlier models that use qualitative variables to predict SMEs' success vs. failure include Reynolds and Miller [56] and Copper et al. (1990, 1991). Recent SMEs success vs. failure prediction model was by Lussier [43] and many other models built around the framework of the

Table 1. A summary of 8 Success vs. Failure models.

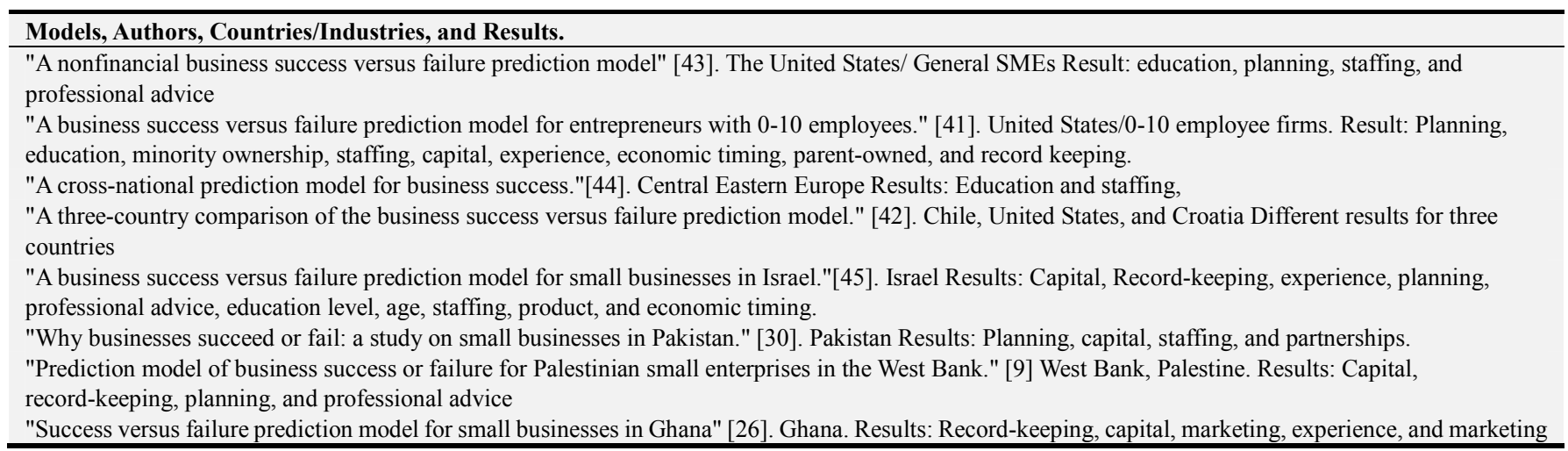


Lussier [43] model [42, 44]. The Lussier [43] success vs. failure was the most recent model and most dominant, and it used 15 independent variables to predict the success vs. failure of SMEs in the United States. The 15 Variables used in the Lussier [43] model includes:

"experience of the industry, control of finances. Keeping of records, capital, management experience, planning professional advisors, education, staffing, product/service timing, economic timing, age of the owner, partners, parents owned a business, minority, and marketing skills" [44].
Lussier [43] study deduced from the 15 variables and arrived at four that influenced the success vs. failure of SMEs in the USA. The four factors include education of owners, professional advice, staffing, and planning [43]. Other researchers replicated the Lussier [43] study in different geographical locations or industries to deduced variables influencing SMEs' success vs. failure. Find in table 1 some of the success vs. failure models that were based on the replication of the Lussier [43].

Table 2. Summary of CSFs of SMEs Theories and their Findings.

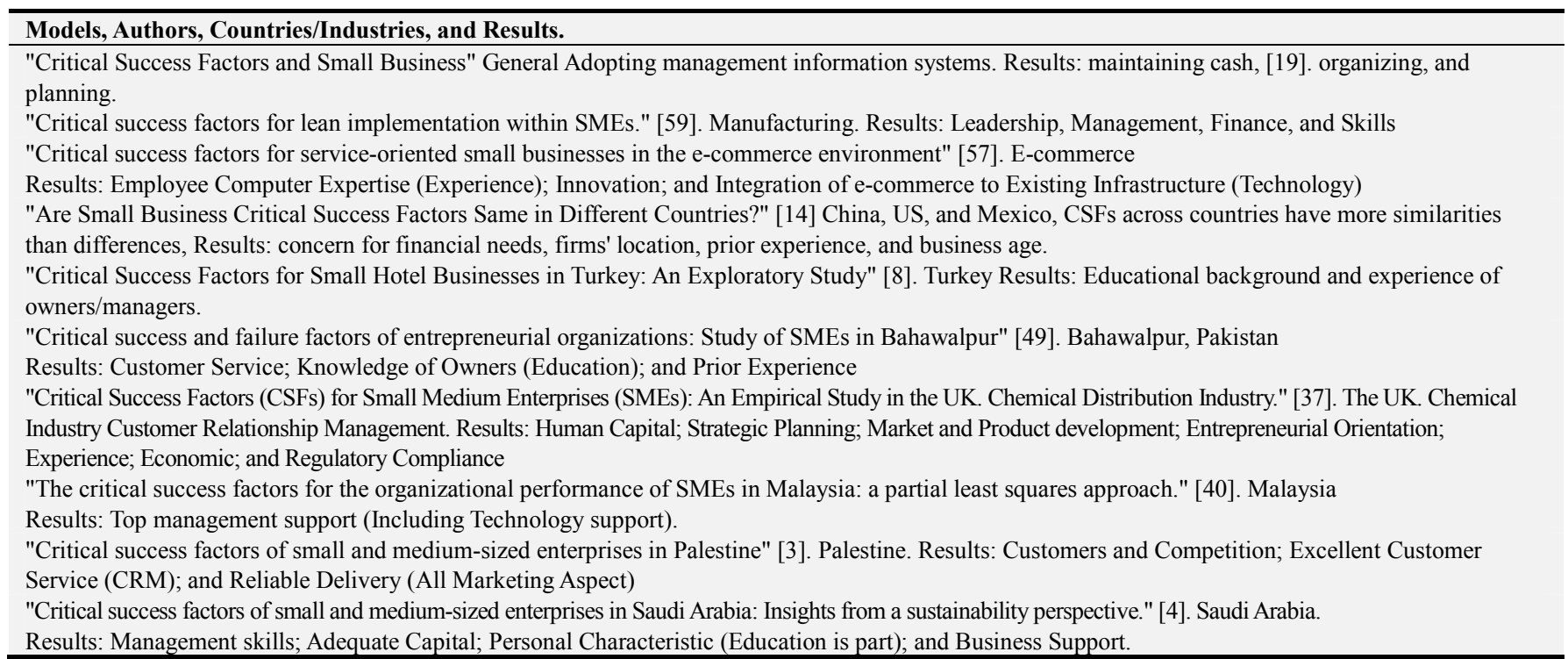

Researchers focused their attention on critical success factors rather than failures by developing models that revealed SMEs' resources that were critical to their success. SMEs' critical success factors are deterministic theories aimed at identifying the resources influencing small businesses' success $[2,17,18,37]$. The SMEs CSFs models identified the managerial variables that influence businesses' success $[2,16]$. CSFs are defined as: "the few key areas of activity in which favorable results are absolutely necessary for a particular manager to reach his goals" [12]. The early CSFs model includes that by Dickson et al. (1984) that established cash as the only CSF of SMEs' success in the USA after utilizing planning, cash, decision-making, organizing, and profits as the independent variables of the study. Many SMEs CSFs were modeled and differ based on the study's location or the SMEs' industry of operation. Table 2 summarizes ten CSFs models for understanding how the models differ according to location or industry.

\section{Relevant Theories and the Underpinning Theory}

Table 2 presented theories relevant to this study because the models investigated SMEs' CSFs across many geographical locations and industries. The study's underpinning model is the one by Lampadarios [37] that investigated the CSFs of SMEs operating in the UK's chemical industry. Like Alfaadhel [2], the Lampadarios [37] model recognizes the external environment factors when deducing the model. Secondly, the 21 independent variables used in the model were identified in the literature review as overlapping across the various CSFs of SMEs' models. The independent variables utilized in the Lampadarios [37] model was:

"entrepreneurial factors: age, education level, entrepreneurial orientation, gender, personality, prior work experience, and management skills.; enterprise factors: age and size of the company, business networks, customer relations management, financial resources, internationalization, human capital, market and product, development, marketing, and strategic planning; business environment legal and regulatory, socio-cultural, economic, political, technological, and ecological and environmental." [37]. Find in table 2 the details of the Lampadarios [37] CSFs of SMEs model.

\section{Research Gaps}

Based on the literature reviewed for the study, twenty-one CSFs identified as findings in SMEs' CSFs in various geographical locations and various industries. The models in the literature review, most notably the underpinning theory by Lampadarios [37], asserts that the study needs to be replicated 
for application of the models in a different geographical location or industry, the study needs to be replicated [2, 37]. Therefore, there are no two models that revealed the same findings. The researcher focused on replicating the CSFs model study in the Jigawa State, Nigeria location to enable positioning of a model that its information can be utilized to develop policies for best business practice to mitigate SMEs' failure by reducing unemployment and poverty trigger socio-economic development in the country. It was also established that most of the CSFs models, including the underpinning theory, do not consider the inclusion of the impact of government support initiatives such as SMEDAN when determining the success influencing variables [53]. The study introduced SMEDAN initiative as mediating variable to determine its impact on the relationship between the CSFs and the SMEs' success. Therefore, the model might reveal how the government support initiative of SMEDAN in promoting the development of SMEs in the country.

\section{Conceptual Model}

There are more than 21 independent variables revealed during the literature review for the study. The study recognized the categorization of the framework of variables into internal and external environmental factors. The variables are a collection of both the resources and capabilities that can make above-average returns uniquely [31]. It is the combination of the unique capabilities and resources that enabled the sustenance of competitive advantage and returns [28]. The resources and capabilities that might be tangible or intangible are based on the resources model; they are used to achieve the organizational goals [29]. They serve as core competencies and capabilities within an organization (internal resources) to achieve performance and growth. Like the internal resources, the external resources facilitate the sustenance of performance and growth triggered by the industrial organization model [11]. The external environment factors, which are variable resources, are not controllable by managers but instead monitored to understand the impact and adjust internal resources to match and sustain growth and performances [28].

The researcher identified seven independent variables; two entrepreneurial (prior work experience and management skills; and education level), three enterprises (finance resources, marketing, and strategic planning), and two environment factors (legal and regulatory; and technology influence) factors for the study. The seven variables are categorized into three based on the framework (entrepreneurial, enterprise, and environment factors) adopted from Lampadarios [37]. Both entrepreneurial and enterprise factors are internal resources that influence SMEs' success. The seven factors' choice as independent variables is because they frequently appear as findings of CSFs models developed for other geographical locations or industries as highlighted in Tables 1 and 2. The study is deduced from the seven factors the CSFs influencing SMEs' success in Jigawa State, Nigeria. Therefore, the dependent variable for the study is the SMEs' success. The SMEDAN initiative was recognized as a factor in the success of SMEs. It thus was introduced as a mediating variable to determine its impact on the relationship between the identified independent variables (CSFs) and the SMEs' success. Find in figure 1 the conceptual model for the study.

Table 3. Summary of Hypotheses.

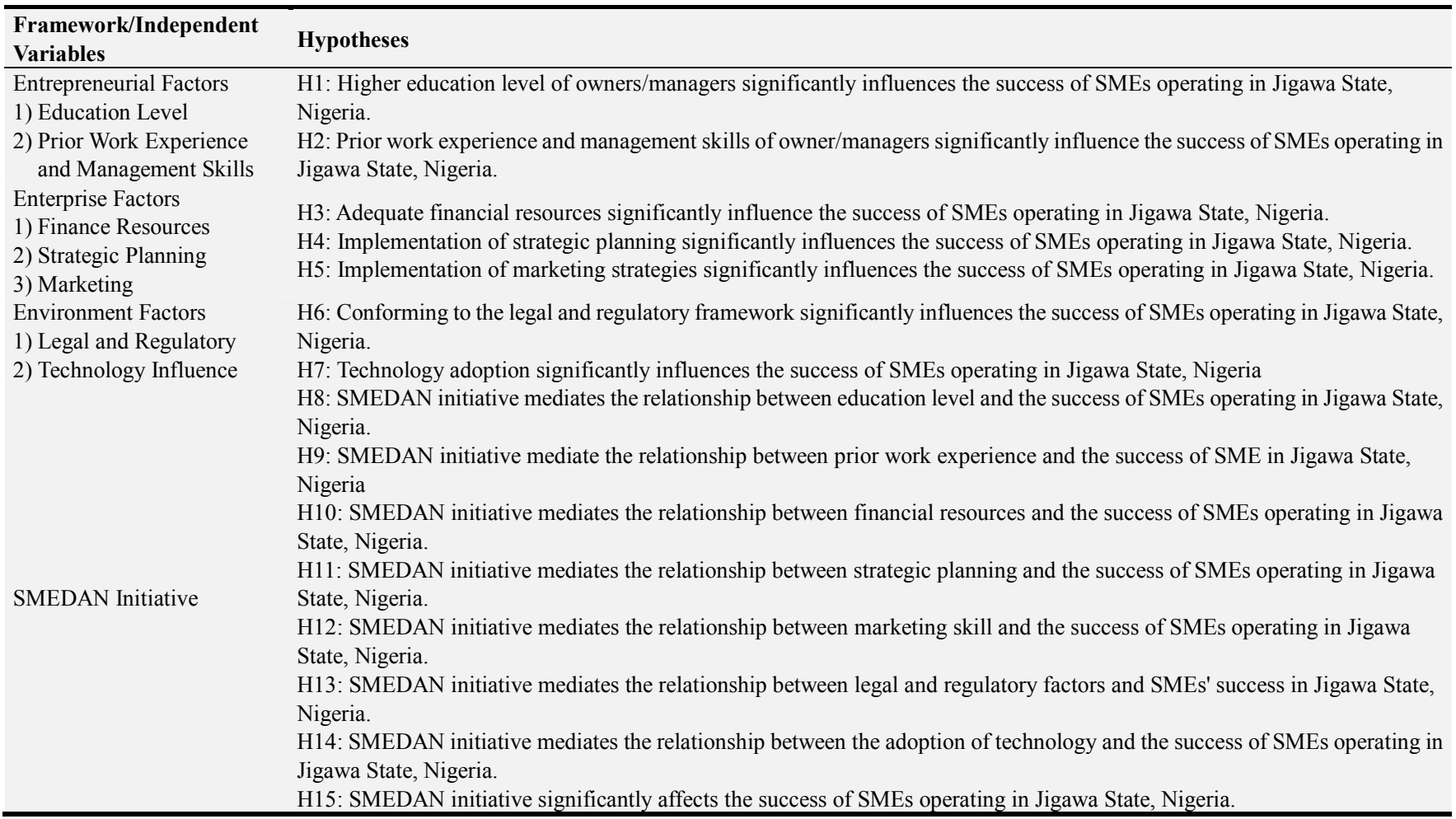




\section{Feasible Hypothesis}

Find in table 3 a summary of hypotheses used to test the three variable's relationships as presented in the conceptual model in figure 1 .

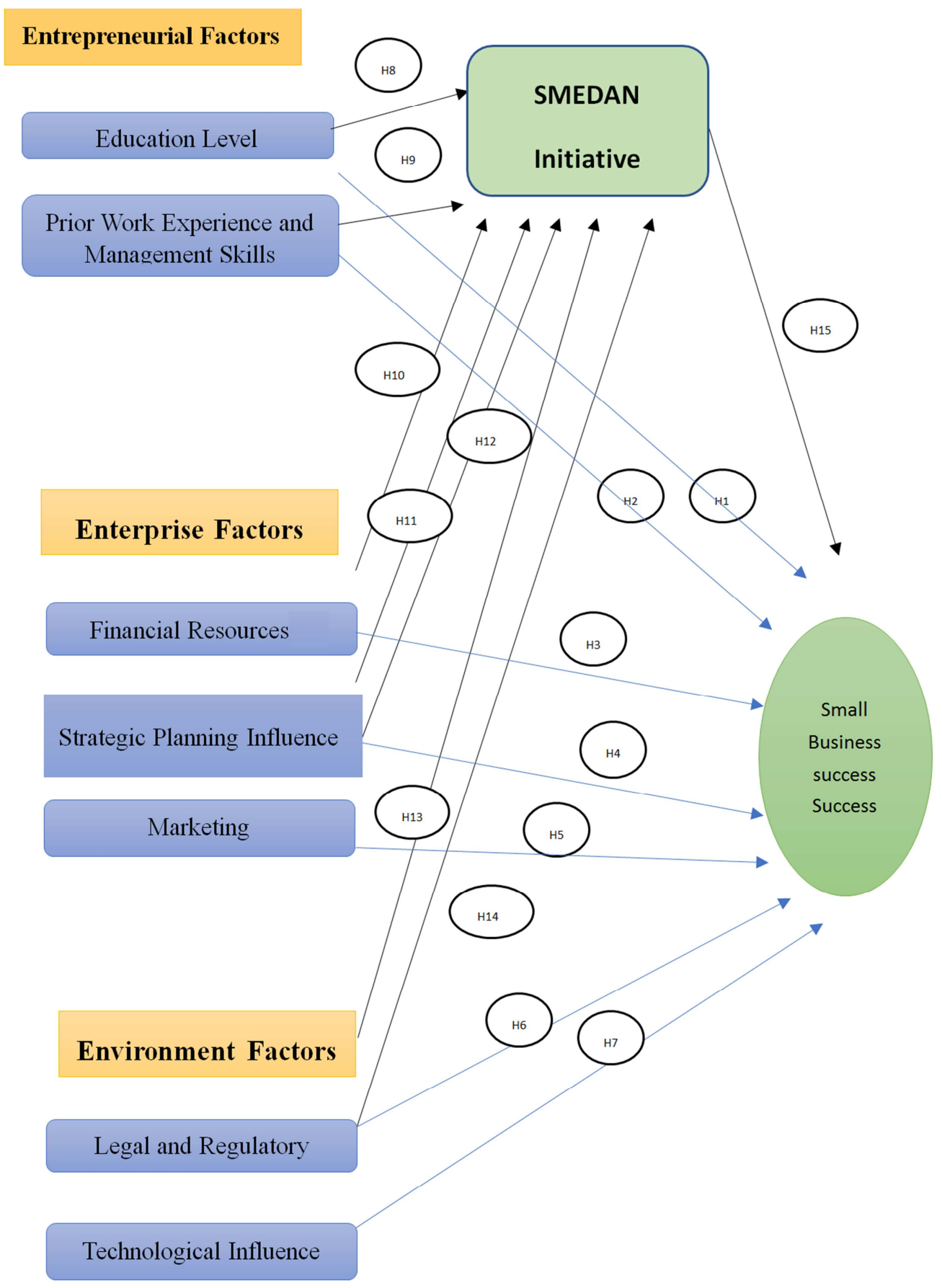

Figure 1. Conceptual Model.

\section{Methodology, Results, Discussions and Conclusion}

\subsection{Methodology}

The mixed research method was adopted for the study. In the qualitative aspect, 15 participants were purposefully identified to be involved in a semi-structured interview. The intention was first to position a grounded theory that might reveal additional variables. Secondly, the qualitative method will reveal an in-depth view of highly skilled respondents who are owners/managers of SMEs. The depth view will reveal additional information that will enable the researcher to make recommendations for future investigations. Like the qualitative study, owners/managers of registered SMEs were 
identified as the study participants. The population list of the study was collected from SMEDAN being the body registering SMEs in Nigeria. The researcher identified 400 owners/managers of SMEs that will participate in answering a self-administered survey questionnaire. Using the scientific formula of calculating, the sample of 400 was determined. The study's questionnaire was adopted from the CSFs model developed by Lampadarious (2015) for SMEs in the UK chemical industry. The study questionnaire's validity and reliability were tested through a pilot study where 50 participants answered the survey questionnaire. The validity and reliability were tested using Cronbach Alpha and principal factor analysis. Using the SPSS statistical package, the pilot study data was analyzed and revealed the conceptual paper's findings.

\subsection{Results and Discussions}

The paper was to present the conceptual/theoretical aspects of a thesis and project the results of a pilot study to understand the research's feasibility/viability. The purpose was to provide a summary of the proposed thesis to unveil the viability of the research. The pilot study is a mock study or mini research [15] Using a fraction (50 respondents) from the 400 respondents for the thesis study, the pilot study was to understand the inadequacies and pitfalls of the study to correct it before the commencement of the thesis study's fieldwork [15]. The pilot study confirmed the correctness of the research instrument. During data collection, 41 participants responded out of the 50 questionnaires distributed, indicating an $83 \%$ response rate. The pilot study data analysis was based on the 41 participants that responded.

The researcher used the SPSS statistical packaged to analyze the data. Using the Cronbach Alpha analysis, the questionnaire's reliability was tested. Cronbach Alpha measures the variable's internal consistency, and a 0.7 is acceptable; some authors require a higher rate [68]. The analysis revealed a Cronbach Alpha of 0.778 , indicating that the self-administered survey questionnaire's internal consistency was reliable. During the principal factor analysis to test the research instrument's validity, the researcher found .000 as Bartlett's test significance level, indicating a statistically significant variable used in the model. The Kaiser-Meyer-Olkin (KMO) test measures the sampling adequacy found a value of 0.73 , indicating the sampling is statistically middling, and the KMO test thumb rule shows it is acceptable. Using the Eigenvalues and Scree Plot rules, the principal factor analysis found four variables with a value of more than 1.0 , indicating that they would be retained for the model analysis. The variables found are prior work experience, education level, finance resources, and marketing.

The analysis of the variables was carried out using the ordinal regression method and found the model's worthiness because the model fitting information shows a significance level of .000 . The Pearson significance value was 1.000, indicated is greater than 0.05 ; therefore, the absorbed data is having the goodness of fit with the fitted data, making the model acceptable.
Table 4. Pseudo R-Square.

\begin{tabular}{ll}
\hline Cox and Snell & .740 \\
Nagelkerke & .910 \\
McFadden & .804 \\
Link function: Logit. & \\
\hline
\end{tabular}

The Pseudo R-Square result found the Nagelkerke value as 0.910 , indicating that the model is $91 \%$ explained. The Nagelkerke value of 0.910 shows that there were enough variables for the model. Find details of the model fitting information in table 4.

Table 5. Result of coefficient and a significant test for a pilot study with Hypothesis interpretations.

\begin{tabular}{llll}
\hline Hypothesis/Variables & Coefficient $\boldsymbol{\beta}$ & $\begin{array}{l}\text { Significant } \\
\text { Value P }\end{array}$ & Remarks \\
\hline H1- Prior work Exp. \& MS & 0.094 & 0.042 & Accept \\
H2- Education Level & -0.317 & 0.131 & Reject \\
H3- Finance Resources & 0.087 & 0.038 & Accept \\
H4- Marketing & 0.086 & 0.138 & Reject \\
H5- Strategic Planning & -0.089 & 0.125 & Reject \\
H6- Legal \& Regulatory & -0.343 & 0.159 & Reject \\
H7-Technology Influence & 0.0085 & 0.023 & Accept \\
H8- SI \& PWE & 0.358 & 0.140 & Reject \\
H9- SI \& Education Level & -0.293 & 0.225 & Reject \\
H10- SI. \& Finance Res. & 0.067 & 0.032 & Accept \\
H11- SI \& Marketing & 0.364 & 0.135 & Reject \\
H12- SI. \& Strategic Plan. & 0.428 & 0.126 & Reject \\
H13- SI \& Legal \& Reg & -0.238 & 0.154 & Reject \\
H14- Tech. Influence & 0.093 & 0.039 & Accept \\
H15-General SMEs' Success & -0.428 & 0.142 & Reject \\
\hline
\end{tabular}

\subsection{Conclusion}

The pilot study revealed that the model explained $91 \%$ of the variables indicating a viable way of bridging the research gap. The model using the ordinal regression analysis will reveal the influence of each of the resources on SMEs' success, which will improve the probability of SMEs success. The pilot study significance test promised an acceptance of five hypotheses out of fifteen (see table 4). The acceptance is based on the thumb rule of accepting a significance value of 0.05 or less. Therefore, with the availability of prior work experience and management skills, finance resources; and technology adoption is available in an SME, there is a great probability that success will be achieved.

Similarly, if the SMEDAN initiative intervenes in improving the provision of adequate finance resources and adopting technology by SMEs, improved success might be achieved. It should be noted that, with 400 participants in the main study for the thesis, there is the likelihood of a significant change in the test results. The significance analysis indicated that there is a relationship between the independent variables. Therefore, the implementation of the actual research by collecting data from the 400 participants might position a model that can be generalized among SMEs of Jigawa State, Nigeria. It is also clear that the model will reveal the needed information by SMEs owners/managers that will be utilized to develop best business practice policies to mitigate SMEs failure triggering socio-economic development through the increase in employment and reduction of poverty. 


\section{References}

[1] Akinbola, O. A., Sanni, S. A., \& Akinbola, O. S.. (2019). Entrepreneurship Support Agencies (ESA) and Development of Small and Medium Enterprises (SMEs) in Nigeria. Economic Studies \& Analyses/Acta VSFS, 13 (1), 29 - 43.

[2] Alfaadhel, S. (2010). An Empirical Study of Critical Success Factors for Small and Medium Enterprises in Saudi Arabia: Challenges and Opportunities, Ph.D. thesis. University of Bradford.

[3] Alfoqahaa, S. (2018). Critical success factors of small and medium-sized enterprises in Palestine. Journal of Research in Marketing and Entrepreneurship, 16 (3), 182-203.

[4] Al-Tit, A., Omri, A., \& Euchi, J. (2019). Critical success factors of small and medium-sized enterprises in Saudi Arabia: Insights from sustainability perspective. Administrative $\begin{array}{lllll}\text { Sciences, } & 9 & (2), & 32 . & \text { doi: }\end{array}$ https://doi.org/10.3390/admsci9020032

[5] Altman, E. (1983). Why businesses fail. Journal of Business Strategy (spring), 15-21.

[6] Altman, E. I. (1984). The success of business failure prediction models: An international survey. Journal of Banking \& Finance, 8 (2), 171-198.

[7] Alves, J. (1978). The Prediction of Small Business Failure: Utilizing Financial and Nonfinancial Data, (dissertation). Massachusetts: University of Massachusetts.

[8] Avcikurt, C., Altay, H., \& Oguzhan Ilban, M.. (2011). Critical success factors for small hotel businesses in Turkey: an exploratory study. Cornell Hospitality Quarterly, 52 (2), 153-164.

[9] Baidoun, S. D. (2018). Prediction model of business success or failure for Palestinian small enterprises in the West Bank. Journal of Entrepreneurship in Emerging Economies, 10 (1), 60-80.

[10] Berezhnytska, U. (2019). Innovative Model of SME Development In 2019, in the 7th International Conference on Modeling, Development and Strategic Management of Economic System (MDSMES 2019) (pp. 139-143). Atlantis Press.

[11] Bowman, E. H., \& Helfat, C. E. (2001). Does corporate strategy matter? Strategic Management Journal, 22, 1-23.

[12] Bullen, C. V., \& Rockart, J. F. (1981). A primer on critical success factors. Center for Information system research MIT, $1-75$.

[13] Buowari, P. E. (2015, November n. d.). Factors required for small business sustainability in Nigeria. Doctoral Study. Minneapolis, Minnesota, United States: Walden University.

[14] Chawla, S. K., Khanna, D., \& Chen, J. (2010). Are small business critical success factors the same in different countries? SIES Journal of Management, 7 (1), 1-12.

[15] Chawla. D. \& Sondhi, N. (2011). Research methodology concepts and cases. New Delhi: Vikas Publishing House PVT LTD.

[16] Christian, M. K. (2015). Characteristics and Critical Success Factors Prioritization of MSMEs in African Agribusiness: A Case of DR. Congo. International Journal of Management Science and Business Administration, 1 (6), 33-43. doi: 10.18775/ijmsba.1849-5664-5419.2014.16.1003.

[17] Cooper, A., Dunkelberg, W., Woo, C., \& Dennis, W. (1990). New Business in America: The Firms and Their Owners. Washington DC: The NFIB Foundation.

[18] Cooper, A., Gascon, J., \& Woo, C. (1991). A Resource-Based Prediction of New Venture Survival and Growth. Proceedings Academy of Management (Summer), 113-119.

[19] Dickinson, R. A., Ferguson, C. R., \& Sircar, S.. (1984). Critical success factors and small business. American Journal of Small Business, 8 (3), 49-57.

[20] Dobbs M. \& Hamilton R. T.. (2007). Small business growth: recent evidence and new directions. International Journal of Entrepreneurial Behaviour and Research, 13 (5), 296-322.

[21] Dosumu, O., Hussain, J., \& El-Gohary, H. (2020). An exploratory study of the impact of government policies on the development of small and medium enterprises in developing countries. In The case of Nigeria. In Start-Ups and SMEs: Concepts, Methodologies, Tools, and Applications (pp. 1205-1218). IGI Global.

[22] Dugguh, S. I. (2015). Critical issues in managing small and medium enterprises: The Nigerian experience. The International Journal of Business \& Management, 39 (9), 52-59. doi: http://search.proquest.com

[23] Eidleman, G. (1995). Z Scores-A Guide to Failure Prediction. The CPA Journal, 65 (2), 52-54.

[24] El-Zayaty, A. (1986). Business Failure Prediction: An analysis of type II prediction errors (Dissertation). New York: City University.

[25] Fan, Q. (2019). An Exploratory Study of Cross Border E-commerce (CBEC) in China: Opportunities and Challenges for Small to Medium Size Enterprises (SMEs). International Journal of E-Entrepreneurship and Innovation (IJEEI), 9 (1), 23-29.

[26] Gyimah, P. M. (2019). Small Business Success or Failure Prediction: A Comparative Study in Ghana and Israel. Journal of Applied Business and Economics, 21 (3). doi: https://doi.org/10.33423/jabe.v21i3.2079

[27] Gyimah, P., Appiah, K. O., \& Lussier, R. N. (2010). Success versus failure prediction model for small businesses in Ghana. Journal of African Business, 21 (2), 215-234.

[28] Hitt, M. A., Ireland, R. D., \& Hoskisson, R. E. (2015). Strategic management competitiveness \& globalization $(11$ th ed). Stamford, CT, USA: Cengage learning.

[29] Hoskisson, R. E., Hitt, M. A., Wan, W. P., \& Yiu, D. (1999). Swings of a pendulum: Theory and research in strategic management. Journal of Management, 25, 417-456.

[30] Hyder, S., \& Lussier, R. N.. (2016). Why businesses succeed or fail: a study on small businesses in Pakistan. Journal of Entrepreneurship in Emerging Economies.

[31] Jacobides, M. G., Winter, S. G., \& Kassberger, S. M. (2012). The dynamics of wealth, profit, and sustainable advantage. Strategic Management Journal, 33, 1384-1410.

[32] Kaigama, Y. M., Talib, N. A., \& Ashari, H. (2016). Moderating effect of financial literacy in the relationship between microfinance banks and small business survival. Indian Journal of Innovations and Developments, 5, (12), 1-6. 
[33] Keats, B. W., \& Bracker, J. S. (1988). Toward a theory of small firm performance: A conceptual model. American Journal of Small Business, 12, 41-58.

[34] Kheng, L. L., \& Muthuveloo, R. (2019). The Influence of Information Technology (IT) Knowledge on Organization Performance with Adaptability to Change as a Moderator among Small Medium Enterprises (SMEs) in Malaysia: A Conceptual Paper.

[35] Kozak, S. (2017). The role and importance of the small business sector in the economic development of the Mazowieckie Province. Zeszyty Naukowe Uniwersytetu Przyrodniczo-Humanistycznego, seria Administracja $i$ Zarzadzanie, 41 (114), 61-70.

[36] Kurochkina, A. A.., Voronkova, O. V., Lukina, O. V., \& Bikezina, T. V. (2019). Management features of small and medium-sized business enterprises. Revista Espacios, 40 (34).

[37] Lampadarios, E. (2015). Critical Success Factors (CSFs) for Small Medium Enterprises (SMEs): An Empirical Study in the UK Chemical Distribution Industry. Post-Doctoral thesis. Leeds Beckett University.

[38] Lin, F., Marshall, A., \& Wu, W. (2020). Historical Development of Chinese SMEs. In Entrepreneurial Innovation and Economic Development. In Dubai and Comparisons to Its Sister Cities (pp. 86-114). IGI Global.

[39] Lipton, D., \& Sachs, J. (1990). Privatization in Eastern Europe: The case of Poland. Brookings Paper on Economic Activity, 2, 293-333.

[40] Lo, M. C., Wang, Y. C., Wah, C. R. J., \& Ramayah, T. (2016). The critical success factors for organizational performance of SMEs in Malaysia: a partial least squares approach. Revista brasileira de gestão de negócios, 18 (61), 370-391.

[41] Lussier \& Corman, R. N. (1996). A business success versus failure prediction model for entrepreneurs with 0-10 employees. Journal of Small Business Strategy, 7 (1), 21-36.

[42] Lussier \& Halabi, R. N. (2010). A three-country comparison of business success versus failure prediction model. Journal of Small Business Management, 48 (3), 360-377. doi: 10.1111/j.1540-627X.2010.00298.x

[43] Lussier, R. N. (1995). A nonfinancial business success versus failure prediction mo. Journal of Small Business Management, $33(1), 8$.

[44] Lussier, R. N., \& Pfeifer, S. (2001). A cross-national prediction model for business success. Journal of small business management, 39 (3), 228-239.

[45] Marom \& Lussier, S. R. (2014). A business success versus failure prediction model for small businesses in Israel. Business and Economic Research, 4 (2), 63-81. doi: http://dx.doi.org/10.5296/ber.v4i2.5997

[46] McLarty, R. P. (2012). Factors influencing the performance of Small to Medium-Sized Enterprises: An empirical study in the Czech Republic. International Journal of Management, 29 (3), 36-47.

[47] Merrick, C., \& Howard, S. G. (2020). The Importance of Small Business and Entrepreneurship as Strategies to Alleviate Poverty. Social Innovations Journal, 2 (2020) 1-4.

[48] Musawa, M. S., \& Ahmad, K. (2019). A Conceptual
Framework for the Influence of Entrepreneurial Orientation and Environmental Dynamism on Marketing Innovation Performance in SMEs. International Journal of Economics and Management Systems, 4, 187-203.

[49] Naqvi, S. W. (2011). Critical success and failure factors of entrepreneurial organizations: Study of SMEs in Bahawalpur. Journal of Public Administration and Governance, 1 (2), 17-22.

[50] Nwekeaku, C., \& Ossai, O. (2019). Small and medium development agency (SMEDAN) and development of small-scale businesses in Nasarawa State. International Journal in Management and Social Science, 7 (8), 9-22.

[51] Obaje, A. (2020). The impact of strategic planning on the performance of small and medium-sized businesses in Nigeria. Ph.D. Thesis. Cardiff Metropolitan University.

[52] Ogechukwu, A. D. (2011). The role of small-scale industry in national development in Nigeria. Universal Journal of Management and Social Sciences, 1 (1), 23-41.

[53] Peter, F. A. (2018). Government financial support and financial performance of SMEs. Academy of Strategic Management Journal, 17 (3), 1-10.

[54] Rehman, N. U., Çela, A., Morina, F., \& Gura, K. S. (2019). Barriers to growth of SMEs in Western Balkan countries. Journal of Management Development., 38 (1), 2-24. doi: https://doi.org/10.1108/JMD-09-2018-0273

[55] Reynolds, P. (1987). New firms: Societal contribution versus potential. Journal of Business Venturing, 3, 231-246.

[56] Reynolds, P., \& Miller, B. (1989). New firm survival: Analysis of a panel's fourth year. In N. C. R. H. Brockhaus, Frontiers of Entrepreneurship Research. Wetzel. Wellesley Mass: Babson College.

[57] Robertson, R. A. (2008). Critical success factors for service-oriented small businesses in the e-commerce environment. Journal of Information Systems Technology \& Planning, 2 (1), 28-31.

[58] Saad, S., Perera, T., Achanga, P., Shehab, E., Roy, R., \& Nelder, G. (2006). Critical Success Factors for Lean Implementation within SMEs. The International Journal of Manufacturing Technology Management, 17 (4), 460-471.

[59] Saari, D. (. (2020). Challenges Faced by SMEs When Accessing Loans from Financial Institutions in Nigeria. A Bachelor's Thesis. Helsinki: Helsinki Metropolia University of Applied Sciences.

[60] SBA. (2017). Starting and Managing. Retrieved from U. S. Small Business Administration: https://www.sba.gov/

[61] Schorch, M., Seifert, F., Syed, H. A., Kotthaus, C., \& Pipek, V. (2020). Doing CSCW research in small and medium enterprises: experiences, options, and challenges. In Proceedings of 18th European Conference on Computer-Supported Cooperative Work. European Society for Socially Embedded Technologies (EUSSET).

[62] Sheppard, J. (1994). Strategy and Bankruptcy: An Exploration into Organizational death. Journal of Management, 20, 795-829.

[63] Smallbone, D., Welter, F., Voytovich, A. \& Egorov, I.. (2010). Government and entrepreneurship in transition economies: the case of small firms in business services in Ukraine. Service Industries Journal, 30, (5) 655-670. 
[64] SMEDAN \& NBS. (2017). SMEDAN and national bureau of statistics collaborative survey: Selected findings 2017. Abuja: SMEDAN and NBS, Nigeria.

[65] SMEDAN, S. a. (2013). SMEDAN and national bureau of statistics collaborative survey: Selected findings 2013. Abuja: SMEDAN. Retrieved from Small and Medium Enterprises Development Agency of Nigeria: http://nigerianstat.gov.ng

[66] Stancu, A., Filip, A., Roșca, M. I., Ioniță, D., Căplescu, R., Cânda, A., \& Roșca, L. D. (2020). Value Creation Attributes-Clustering Strategic Options for Romanian SMEs. Sustainability, 12 (17), 7007.

[67] Stanković, M., Mrdak, G., \& Stojanović, S.. (2018). The importance of small and medium enterprises in modern economy. Knowledge International Journal, 28 (5), $1619-1624$.

[68] Statistics How To. (2020). Cronbach's Alpha: Simple Definition, Use, and Interpretation. Retrieved November 22, 2020, from Statistics How To: https://www.statisticshowto.com/cronbachs-alpha-spss/
[69] Storey, D., Keasey, K., Watson, R., \& Wynarczyk, P. (1987). Performance of small firms: Profits, jobs, and failure. London: Croom Helm.

[70] Tobar-Pesántez, L., \& Solano-Gallegos, S. (2018). The Importance of Small and Medium Enterprises in the City of Cuenca-Ecuador and Their Contribution to the Creation of Employment. Academy of Accounting and Financial Studies Journal, 22 (2), 1-17.

[71] Van, H. T. T., \& Ha, D. B. (2017). Small and Medium Enterprises in Vietnam. International Conference of the Korean International Trade Association, 148-161.

[72] Yoshino, N., \& Taghizadeh Hesary, F. (2016). Major challenges facing small and medium-sized enterprises in Asia and solutions for mitigating them. Asian Development Bank Institute Working Paper Series, 564 (April 2016). Retrieved from https://www.adb.org/sites/default/files/publication/182532/adbiwp564.pdf 